\title{
Mechanisms of histamine stimulated secretion in rabbit ileal mucosa*
}

\author{
B D LINAKER, $†$ J S McKAY, \\ From the Department of Medicine, Hope Hospital (University of Manchester School of Medicine), \\ Salford, Lancashire
}

SUMMARY Histamine is present in high concentrations in the intestine and we investigated the possibility that it might have a role here in intestinal transport. When added to the basal side of rabbit ileal mucosa in vitro histamine $\left(10^{-4} \mathrm{M}\right)$ induced a short-lived increase in electrical potential difference and short circuit current. It inhibited net chloride absorption but did not influence sodium transport. Alkali secretion, measured by a $\mathrm{pH}$ stat technique, was inhibited, suggesting that bicarbonate secretion was reduced. Both the electrical and ion flux responses to histamine were blocked by the $\mathrm{H} 1$ receptor blocker diphenhydramine, but not by the $\mathrm{H} 2$ receptor blocker cimetidine. The presence of specific $\mathrm{H}_{1}$ histamine receptors was further supported by shifts in the dose-response curve to histamine by four different concentrations of diphenhydramine. Calculation of a $\mathrm{pA}_{2}$ value from these 'Schild' plots provided a figure of 7.85, which is similar to that for $\mathrm{H}_{1}$ receptors in other tissues. Aminoguanidine, a histaminase blocker, had no electrical effects alone but shifted the histamine dose response curve to the left. These studies indicate that histamine inhibits chloride absorption and alkali secretion, possibly by influencing a chloride/bicarbonate exchange process, through specific mucosal $\mathrm{H}_{1}$ receptors. Enhancement of histamine effects by a histaminase inhibitor suggests that histaminases are present in the intestinal mucosa and supports the possibility of a role for endogenous histamine in influencing ion transport. The observations indicate a mechanism by which absorption might be impaired in diseases in which histamine is liberated locally in the intestine.

The intestinal mucosa contains a rapidly turning over pool of histamine which appears to be derived largely from non-mast cell sources. ${ }^{1-3}$ Its physiological role here, however, is uncertain, although in systemic mastocytosis, in which histamine is liberated locally in high concentration, diarrhoea is a feature ${ }^{34}$ It is possible therefore that histamine may act as an intestinal secretogogue and this possibility was examined in rabbit ileal mucosa in vitro.

\footnotetext{
*Part of this work was presented at a meeting of the European Society for Clinical Investigation (March 1979) and the British Society of Gastroenterology (September 1979).

†Present address: Department of Medicine. Warrington General Hospital, Warrington WA5 1QG.

$\ddagger$ Present address: Department of Gastroenterology, Royal Liverpool Hospital, Liverpool L69 3BX.

§Address for correspondence: Professor LA Turnberg. Department of Medicine, Hope Hospital (University of Manchester School of Medicine), Salford M6 8HD, Lancashire, UK.

Received for publication 5 May 1981
}

\section{Methods}

Using an in vitro technique previously described in detail, ${ }^{5}$ segments of stripped ileal mucosa were mounted in Perspex flux chambers. Tissues were bathed on both sides in buffer maintained at $37^{\circ} \mathrm{C}$ and of composition $\mathrm{Na} 146, \mathrm{~K} 4 \cdot 2, \mathrm{Cl} 125 \cdot 8$, $\mathrm{HCO}_{3} 26 \cdot 6, \mathrm{H}_{2} \mathrm{PO}_{4} 0.2 \mathrm{HPO}_{4} 1 \cdot 2, \mathrm{Ca} 1 \cdot 2, \mathrm{Mg} \mathrm{1} \cdot 2$, glucose $10 \mathrm{mMol} / 1$, and $\mathrm{pH} 7 \cdot 4$. The buffer was stirred and oxygenated by a $95 \%$ oxygen $5 \% \mathrm{CO}_{2}$ gas lift system. In the experiments using a bicarbonate-free buffer, chloride was substituted for bicarbonate and $100 \% \mathrm{O}_{2}$ was bubbled through the buffer. Transmucosal potential difference was measured via saturated $\mathrm{KCl}$ in agar bridges and calomel electrodes using a high impedance digital voltmeter. Sodium chloride in agar bridges to silver/silver chloride electrodes were used to transmit the short-circuit current. This was adjusted initially each minute and later every five minutes. Experiments conducted later were performed using 
an automatic voltage clamp apparatus, which continuously adjusted the short-circuit current. Corrections were made for the fluid gap resistance as described by Field et al. ${ }^{6}$ Tissue resistance (R) was calculated from the short-circuit current and potential difference and expressed in Ohms per $\mathrm{cm}^{2}$.

Short-circuit current was converted to net ion flux in $\mu \mathrm{mol} / \mathrm{cm}^{-2} / \mathrm{h}$ by multiplication by a factor of $3.6 \times 10^{3}$

0.033 derived from $\frac{}{A F}$ where $A$ equals area

of exposed tissue and F is Faraday's constant.

Ion fluxes were determined in tissue pairs obtained from the same animal and with resistances varying by less than $25 \%$. Usually eight tissues were set up at the same time. Steady state fluxes were usually obtained 15 minutes after addition of isotopes and thus flux measurements were started 30 minutes after isotope addition to ensure equilibration. Fluxes were measured during the 15 minute period before addition of drugs (control flux) and for 15 to 30 minutes starting 15 minutes after addition of drugs when equilibrium conditions had been reestablished. Control fluxes were also measured in some experiments during four consecutive 15 minute periods. Unidirectional fluxes from mucosa to serosa and from serosa to mucosa were measured in each tissue pair after the addition of $0.5 \mu \mathrm{Ci}^{22} \mathrm{Na}$ and $2 \cdot 5 \mu \mathrm{Ci}^{36} \mathrm{Cl}$ to the mucosal side of one tissue and the serosal side of its paired tissue. One millilitre samples were taken from mucosal and serosal solutions and replaced by $1 \mathrm{ml}$ warm unlabelled buffer. Calculation of fluxes was performed as described previously ${ }^{5}$ and fluxes were determined under short-circuit conditions with minimal interruption to read the spontaneous potential difference.

With the use of a $\mathrm{pH}$ stat technique ${ }^{7}$ net alkali secretion was determined on the mucosal side of the tissue bathed in the bicarbonate free buffer and bubbled with $100 \%$ oxygen. The serosal bathing solution was a bicarbonate buffer bubbled with $95 \%$ oxygen $5 \% \mathrm{CO}$. The mucosal solution was maintained at $\mathrm{pH}$ of $7 \cdot 4$ by continuous titration with $5 \mu \mathrm{mol} / 1$ hydrochloric acid titrant. This was carried out with an Autotitrator 11 and Autoburette ABU 13 (Radiometer, Cophenhagen) which very accurately deliver the small volumes of hydrochloric acid needed to maintain the $\mathrm{pH}$ constant as measured by combined electrodes GK2321C and GK2332C. The volume of titrant needed to maintain the $\mathrm{pH}$ constant during a 30 minute control period and one hour after addition of histamine was recorded at five minute intervals. From the amount of acid added it is possible to calculate the rate of alkali (presumably bicarbonate) secreted. Potential difference and short-circuit current were also measured during this experiment.

An attempt was made to identify specific histamine receptors by studying the effect, on a histamine dose-response curve, of four different concentrations of the specific $\mathrm{H}_{1}$ receptor antagonist diphenhydramine and calculating a $\mathrm{pA}_{2}$ value from these dose response curves ${ }^{89}$. pAx values, a measure of drug antagonism, are an accepted basis for receptor classification based on the hypothesis that agonists and antagonists compete for receptors according to mass law ${ }^{10}$. The same pAx values should be obtained with similar receptors in different tissues with the same agonist/antagonist combination ${ }^{9}$. pAx is defined as the negative logarithm of the molar concentration of the antagonist which will reduce the effect of a multiple dose of the agonist (x) to that of a single doses. More simply, $\mathrm{pA}^{\mathrm{s}}$ is the negative logarithm of the molar concentration of antagonist which halves the sensitivity of the preparation to the agonist ${ }^{11}$. These values are dependent on contact time between antagonist and tissue $^{\mathrm{x}}$. A fixed time of 14 minutes was taken in these experiments to allow comparison with published data on $\mathrm{pA}_{2}$ in other tissues. For dose response and agonist/antagonist interaction studies only one dose of agonist or antagonist was used in any single piece of mucosa to avoid persistence of effects and the possibility of tachyphylaxis.

Aminoguanidine, a specific inhibitor of the enzyme responsible for histamine catabolism, was used to determine whether histaminase was present in intestinal mucosa. Tissues were pretreated with $10^{-4} \mathrm{M}$ aminoguanidine (a dose which completely inhibits histaminase ${ }^{12}$ ) and histamine dose response, using maximal percentage potential difference increases, were determined and compared with results from control tissues.

Statistical analysis was made using Student's $t$ test for paired and unpaired samples and variability is expressed as mean \pm one standard error of the mean. Materials used were histamine acid phosphate (Sigma Chemical Corporation), diphenhydramine (Park Davies Ltd), cimetidine (Smith, Kline \& French Ltd), and aminoguanidine (Sigma Chemical Corporation).

\section{Results}

Histamine added to the aerosol side of ileal mucosa significantly increased potential difference, shortcircuit current, and tissue resistance, the changes in potential difference and short-circuit current being maximal at two minutes post histamine (Fig. 1). Potential difference returned to control values within 10 minutes but resistance remained raised for 


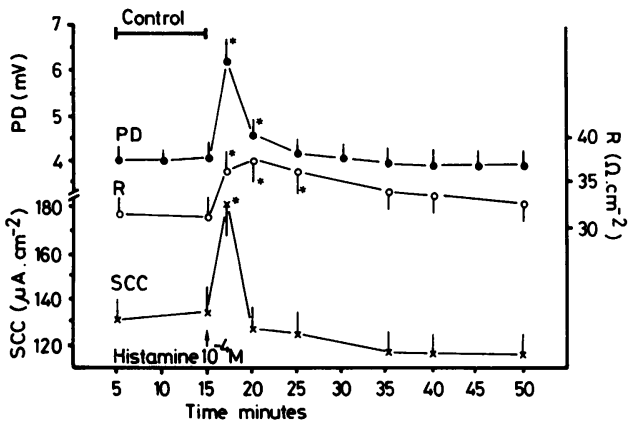

Fig. 1 Changes in potential difference, short-circuit current, and resistance of ileal mucosa after histamine $10^{-4} \mathrm{M}$ added to rabbit ileal mucosa bathed in glucose buffer (mean $\pm S E M$ shown). *Significantly different fiom control response $(\mathrm{P}<0.001)$. at least 30 minutes after histamine was added. The electrical response was reproducible and doserelated. A dose response curve (Fig. 2) demonstrated that the maximal response was achieved at a concentration of $10^{-4} \mathrm{M}$ and the smallest dose at which a significant response was noted was $10^{-5} \mathrm{M}$. Histamine in concentrations greater than $10^{-3} \mathrm{M}$ failed to increase potential difference or shortcircuit current. Histamine added to the mucosal side of tissues failed to produce an electrical response (Fig. 2).

The $\mathrm{H} 2$ receptor blocker cimetidine in concentrations between $10^{-2}$ and $10^{-4} \mathrm{M}$ did not influence electrical values in control tissues, nor did it influence the electrical response to histamine. However, equimolar concentrations of diphenhydramine, an H1 receptor blocker, completely prevented the
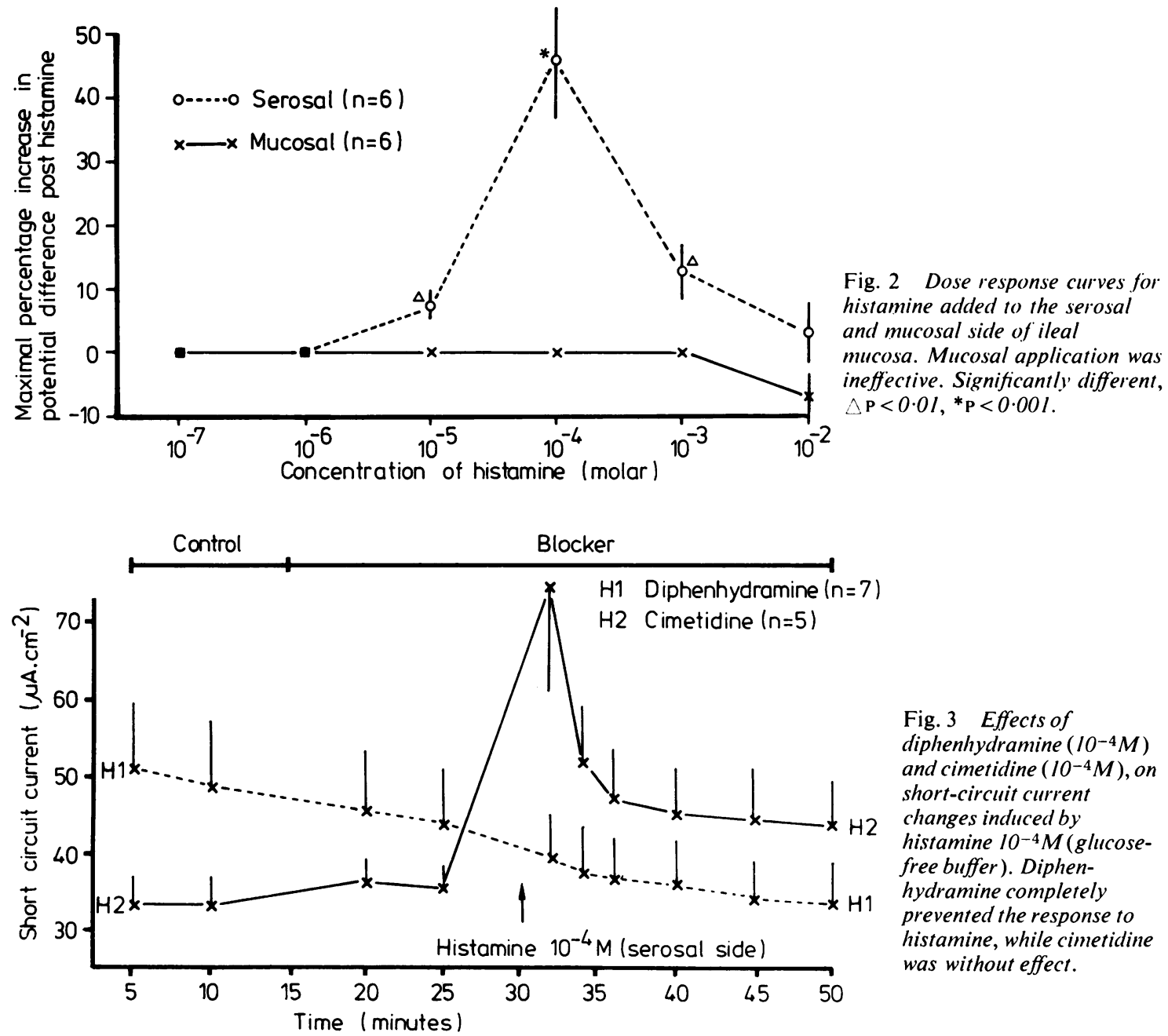

Fig. 3 Effects of diphenhydramine $\left(10^{-4} \mathrm{M}\right)$ and cimetidine $\left(10^{-4} \mathrm{M}\right)$, on short-circuit current changes induced by histamine $10^{-4} \mathrm{M}$ (glucosefree buffer). Diphenhydramine completely prevented the response to histamine, while cimetidine was without effect. 
histamine-induced electrical response (Fig. 3). In addition, diphenhydramine lowered potential difference and short-circuit current in tissues bathed in glucose-free buffer but not in those in glucosecontaining buffer.

The influence of four different concentrations of diphenhydramine on the dose response curve to histamine is shown in Fig. 4, the curve being shifted to the right by the increasing concentrations of $\mathrm{H} 1$ blocker. The shift to the right of the concentration of histamine required to produce a half maximal control electrical response was used to calculate a $\mathrm{pA}_{2}$ value as described in the legend to Figs. 4 and 5 and shown in Fig. 5. From this graph a $\mathrm{pA}_{2}$ value of 7.85 was calculated, which is similar to $\mathrm{pA}_{2}$ values for $\mathrm{H} 1$ receptors in other tissues.

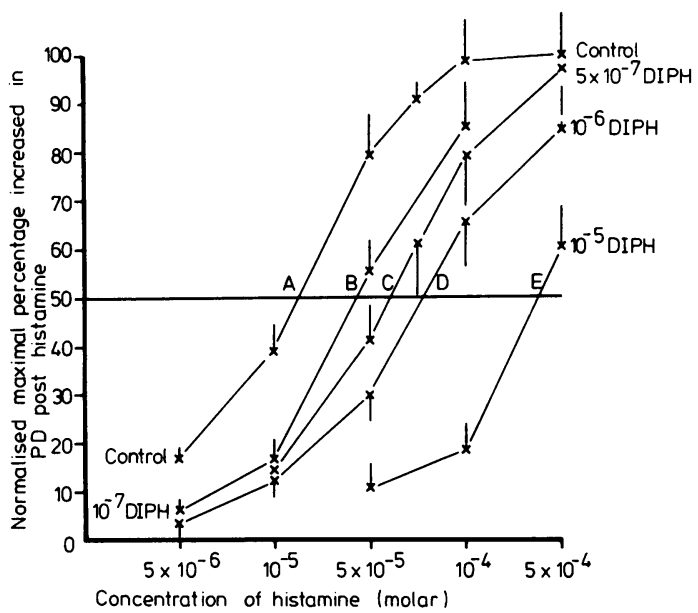

Fig. 4 Dose response curves for histamine-induced increases in potential difference with and without diphenhydramine (DIPH) in rabbit ileum. The maximum increase in potential difference obtainable with histamine $(2.2 \mathrm{mV})$ was taken as $100 \%$ and all other results related to that value. The dose response curve to histamine is increasingly shifted to the right by $10^{-7}, 5 \times 10^{-7}, 10^{-6}$ and $10^{-5} \mathrm{M}$ diphenhydramine. The extent to which the dose of histamine required for a half maximal control response is shifted by' the different concentrations of $\mathrm{HI}$ blocker indicated at $A, B, C, D$, and $E$ was used to calculate the $\mathrm{pA}_{2}$ value as shown in Fig. 5.

In the histaminase inhibition studies, aminoguanidine $10^{-4} \mathrm{M}$ had no electrical effect when given alone. However, in tissues pretreated with aminoguanidine, histamine provoked an electrical response at lower concentrations than in control tissues. The curve was shifted to the left by aminoguanidine pretreatment (Fig. 6), suggesting that histaminases are present in the tissues.

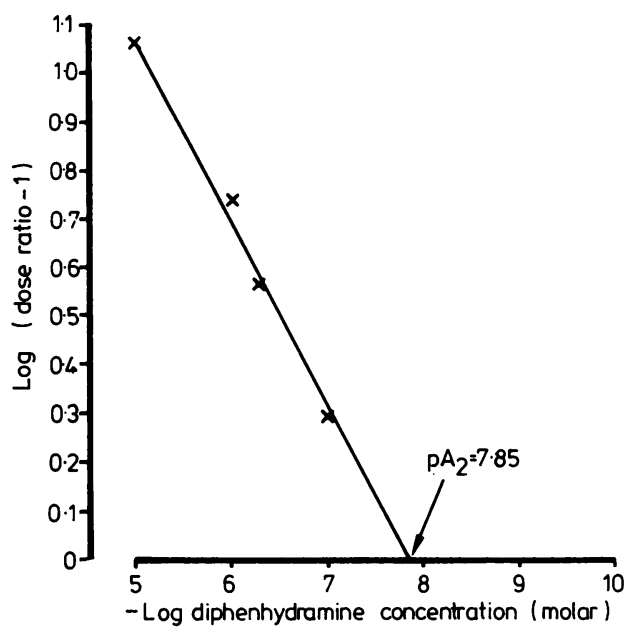

\begin{tabular}{llll}
\hline $\begin{array}{l}\text { Dose ratio } \\
\text { (from Fig. 4) }\end{array}$ & Log (dose ratio-1) & $\begin{array}{l}\text { Diphenhydramine } \\
\text { concentration } \\
(\text { mol) }\end{array}$ & $\begin{array}{l}- \text { Log } \\
\text { diphenhydraminc } \\
\text { concentration }\end{array}$ \\
\hline BA $=3.0$ & Log $2 \cdot 00=0.30$ & $10^{-7}$ & $7 \cdot 0$ \\
$\mathrm{CA}=4 \cdot 75$ & Log $3 \cdot 75=0.57$ & $5 \times 10^{-7}$ & $6 \cdot 3$ \\
$\mathrm{DA}=6.50$ & $\log 5 \cdot 50=0.74$ & $10^{-6}$ & 6.0 \\
$\mathrm{EA}=12.5$ & Log $11 \cdot 50=1.06$ & $10^{-5}$ & 5.0 \\
\hline
\end{tabular}

Fig. 5 Plot of $\log$ (dose ratio- 1 ) vs-log antagonist concentration to determine $p A^{2}$ (Schild plots).

ION FLUXES

Preliminary studies with control tissues bathed in glucose buffer alone showed that after 30 minutes' equilibration following addition of isotopes there was no significant change in sodium, chloride, or residual ion fluxes during four consecutive 15 minute periods $(n=8)$.

Steady state fluxes were achieved by 15 minutes after addition of histamine. Fluxes in control tissues and during the periods $15-30$ minutes after histamine are shown in the Table (A). Net chloride absorption was significantly reduced $(P<0.01)$ due to a reduction in mucosa to serosa flux $(P<0.01)$. It should be noted that these fluxes were measured at a time when the transient electrical responses had largely resolved. There was no obvious effect on sodium transport. The calculated residual ion flux, which represents the unmeasured ions making up the total net ionic movement inferred from the short circuit current, was significantly reduced after histamine $(P<0.01)$. This result is compatible with a reduced secretion of bicarbonate ions (or increased secretion of hydrogen ions).

Alkali secretion, measured by the $\mathrm{pH}$ stat technique, confirmed that this residual ion flux was likely to be due, at least in part, to movement of bicarbonate or hydrogen ions. As shown in Fig. 7, alkali secretion was reduced after histamine from 


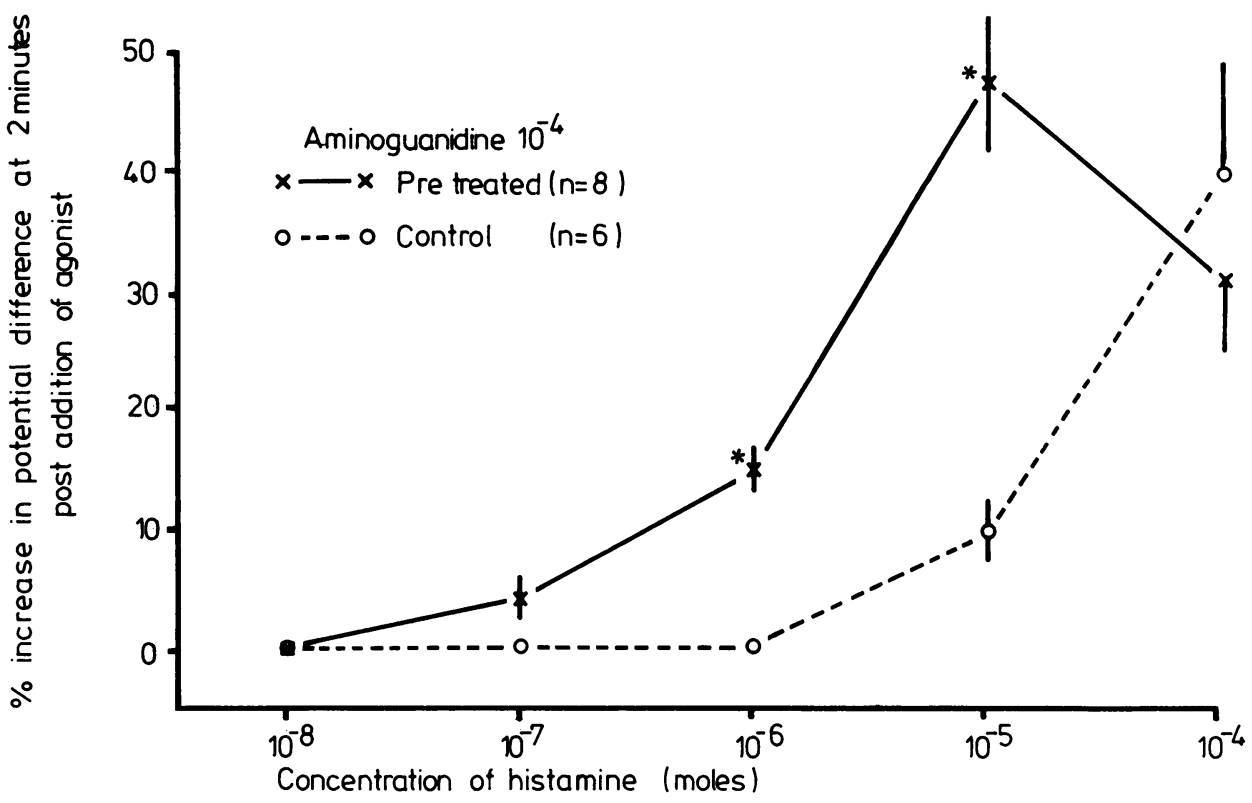

Fig. 6 Dose response curves for histamine in control and aminoguanidine $\left(10^{-4} \mathrm{M}\right)$ pretreated tissues. The curve is shifted to the left by aminoguanidine. (Mean \pm SEM shown.) * Significantly different from control response $(\mathrm{P}<0.001)$.

Table Ion fluxes and short-circuit current in rabbit ileal mucosa: responses to histamine $(A)$; histamine in diphenhydramine pretreated tissues $(C)$; diphenhydramine alone $(B)$

\begin{tabular}{|c|c|c|c|c|c|c|c|c|}
\hline & $J m s$ & $\begin{array}{l}\mathrm{Na} \\
\mathrm{Jsm}\end{array}$ & Jnet & $J m s$ & $\begin{array}{l}C 1^{-} \\
J_{s m}\end{array}$ & Jnet & $S C C$ & $J_{\mathrm{R}} n e t$ \\
\hline \multicolumn{9}{|c|}{ A Histamine $10^{-4} M \quad(\mathrm{n}=9)$} \\
\hline \multirow[t]{2}{*}{ Control } & $16 \cdot 3$ & $10 \cdot 2$ & $6 \cdot 1$ & $12 \cdot 2$ & $8 \cdot 1$ & $4 \cdot 1$ & $5 \cdot 0$ & $2 \cdot 9$ \\
\hline & $\therefore 0.6$ & \pm 0.9 & $\pm 1 \cdot 1$ & $\pm 0 \cdot 3$ & $\pm 0 \cdot 8$ & \pm 0.9 & $\pm 0 \cdot 4$ & $\pm 0 \cdot 7$ \\
\hline \multirow{2}{*}{ Histamine } & $15 \cdot 5$ & $9 \cdot 6$ & $5 \cdot 9$ & $9 \cdot 2+$ & $8 \cdot 7$ & $0.5+$ & $4.4+$ & $-1 \cdot 0+$ \\
\hline & \multicolumn{2}{|c|}{ B Diphenhydramine $\left(10^{-4} M\right)$ alone $(n=11)$} & $\pm 1 \cdot 1$ & $\pm 0 \cdot 7$ & $=1 \cdot 1$ & $\pm 1 \cdot 2$ & \pm 0.4 & \pm 0.9 \\
\hline \multirow[t]{2}{*}{ Contro1 } & $12 \cdot 5$ & $9 \cdot 1$ & $3 \cdot 3$ & $9 \cdot 9$ & $8 \cdot 4$ & 1.6 & 3.4 & 1.5 \\
\hline & $\pm 0 \cdot 8$ & $\pm 0 \cdot 7$ & $\pm 0 \cdot 6$ & \pm 0.5 & \pm 0.5 & \pm 0.4 & \pm 0.4 & \pm 0.8 \\
\hline \multirow[t]{2}{*}{ Diphenhydramine } & $12 \cdot 2$ & $8 \cdot 9$ & $3 \cdot 3$ & $9 \cdot 5$ & $8 \cdot 1$ & $1 \cdot 4$ & $2 \cdot 8$ & 0.9 \\
\hline & $\pm 1 \cdot 0$ & $\pm 0 \cdot 8$ & $\pm \mathbf{0} \cdot \mathbf{8}$ & \pm 0.6 & \pm 0.7 & \pm 0.4 & \pm 0.3 & $\pm 1 \cdot 1$ \\
\hline \multicolumn{9}{|c|}{ C Histamine $10^{-4}$ after diphenhydramine $10^{-4} \dot{M} \quad(\mathrm{n}=9)$} \\
\hline \multirow[t]{2}{*}{ Control (no drug) } & 12.9 & $8 \cdot 3$ & $4 \cdot 6$ & $9 \cdot 2$ & $8 \cdot 2$ & 0.9 & $4 \cdot 8$ & $1 \cdot 2$ \\
\hline & 0.5 & \pm 0.6 & $\pm 0 \cdot 6$ & $\pm \mathbf{0} \cdot \mathbf{3}$ & $\pm 0 \cdot 3$ & \pm 0.4 & $\pm 0 \cdot 3$ & $\$ 0.6$ \\
\hline \multirow[t]{2}{*}{ Histamine } & $12 \cdot 6$ & $7 \cdot 7$ & $4 \cdot 8$ & $9 \cdot 6$ & $7 \cdot 8$ & 1.8 & $3 \cdot 4 \ddagger$ & 0.4 \\
\hline & $50 \cdot 7$ & $\therefore 0.6$ & \pm 0.9 & $\pm 0 \cdot 8$ & $\pm 1 \cdot 1$ & $0 \cdot 2$ & $\pm 1 \cdot 1$ & \pm 0.6 \\
\hline
\end{tabular}

In each instance control fluxes for the 15 minutes before addition of drugs and responses to histamine or diphenhydramine were measured in the periods 15 to 30 minutes after drug addition. In study $(\mathrm{C})$ histamine was added 15 minutes after diphenhydramine and fluxes measured 15 to 30 minutes after histamine. Fluxes and short-circuit current are in $\mu \mathrm{mol} / \mathrm{cm}^{-2} / \mathrm{h} \mathrm{Jms}=$ flux from mucosa to serosa. Jsm $=$ flux from serosa to mucosa. Jnet $=$ net flux. $J_{\mathrm{R}}$ net $=$ calculated residual ion flux. Mean $\pm S E M ;{ }^{*} \mathrm{P}<0.02 ;+\mathrm{P}<0.01 ; \ddagger \mathrm{P}<0.001$.

$2 \cdot 0 \pm 0 \cdot 3$ to $1 \cdot 4 \pm 0 \cdot 3 \mu \mathrm{mol} / \mathrm{cm}^{-2} / \mathrm{h}^{1}(\mathrm{n}=8, \mathrm{P}<0 \cdot 01)$.

Although the flux data for the 15 minute period immediately after histamine addition are not presented, net chloride absorption was reduced $\left(4 \cdot 1\right.$ to $\left.1.5 \mu \mathrm{mol} / \mathrm{cm}^{-2} / \mathrm{h}, \mathrm{P}<0.02, \mathrm{n}=9\right)$ because of a decrease in mucosa to serosa flux $(12 \cdot 2$ to $9 \cdot 8 \mu \mathrm{mol} /$ $\mathrm{cm}^{-2} / \mathrm{h}, \mathrm{P}<0 \cdot 01, \mathrm{n}=9$ ). The time courses for the effect of histamine on alkali secretion (Fig. 7) and on chloride flux are thus similar.

Ion fluxes were measured in response to histamine after pretreatment with diphenhydramine $\left(10^{-4} \mathrm{M}\right)$. The changes in chloride fluxes induced by histamine 


\begin{tabular}{|l|c|c|r|}
\hline $\mathrm{JCI}^{\text {net }}$ & $+4 \cdot 1$ & +1.5 & +0.5 \\
\hline $\mathrm{JCI}^{\mathrm{ms}}$ & 12.2 & 98 & $9 \cdot 2$ \\
\hline $\mathrm{JCI}^{\mathrm{Sm}}$ & 8.1 & 8.3 & 8.7 \\
\hline
\end{tabular}

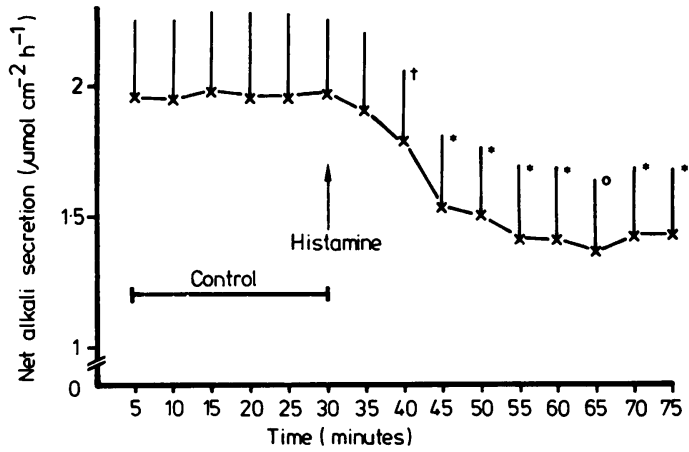

Fig. 7 Effects of histamine $\left(5 \times 10^{-4} \mathrm{M}\right)$ on alkali secretion $\left(\mu \mathrm{mol} / \mathrm{cm}^{-2} / \mathrm{h}\right)$ in rabbit ileum measured by $\mathrm{pH}$ stat technique. (Mean $\pm S E M$ shown.) $(N=8$.) Significantly different from control response $(\dagger \mathrm{P}<0.05$, ${ }^{*} \dot{\mathrm{p}}<0.01,{ }^{\circ} \mathrm{P}<0.001$. (Net and undirectional fluxes of $\mathrm{Cl}^{-}$, obtained in a different set of tissues, during the same time period, are shown for comparison.)

were shown to be completely prevented by this $\mathrm{H} 1$ blocker, although a slight fall in short-circuit current persisted (Table, C). Diphenhydramine $\left(10^{-4} \mathrm{M}\right)$ alone did not influence sodium or chloride fluxes and a fall in residual ion flux was not statistically significant (Table, B). The decrease in short-circuit current induced by diphenhydramine in tissues in glucose buffer was not significantly different from the slight fall in short-circuit current seen in control tissues over the same time period.

\section{Discussion}

The presence of histamine receptors in the musculature of the small intestine has been supported by several investigations ${ }^{13-15}$ but their presence in intestinal mucosa has not been well described. Infusions of histamine into the mesenteric arterial system of dogs provoked marked secretion into the lumen, but it was suggested that this was due to leakage of fluid through a capillary network whose permeability had become markedly increased. ${ }^{16}$ Recent studies ${ }^{17}$ with a number of histamine receptor antagonists, however, have supported the idea that histamine receptors may be involved in intestinal ion transport, at least in rabbit ileum. Interpretation of the latter studies is dependent on the specificity of the histamine receptor antagonists used (see below) but the current studies lend additional weight to the concept of specific $\mathrm{H} 1$ receptors in rabbit ileal mucosa.

The electrical responses to histamine were shown to be specifically blocked by diphenhydramine in a dose-related manner. The calculated value of 7.85 for $\mathrm{pA}_{2}$ is very similar to the values calculated for histamine/diphenhydramine relationships in other tissues $\left(8 \cdot 1,8.0\right.$, and 7.8 in guinea-pig ileal muscle ${ }^{8}$ ${ }^{18}{ }^{19} ; 7.8$ in guinea-pig trachea; $; 9$ and 7.8 in guineapig lung ${ }^{9}$ ) supporting the interpretation that specific $\mathrm{H} 1$ receptors are involved.

The residual ion flux changes were shown, by the $\mathrm{pH}$ stat technique, to be due, at least in part, to a reduction in bicarbonate secretion. The residual ion flux change was larger than the change in titratable alkali but this is hardly surprising because the former was a calculated figure derived from the sum of $\mathrm{Na}$ and $\mathrm{Cl}$ fluxes and short-circuit current and the latter a direct measure in a different group of tissues at a different time. It is thus not possible to judge whether all or only a part of the change in residual ion flux in these studies could be attributed to bicarbonate (of $\mathrm{H}+$ ) movement changes. The results presented here thus support the possibility of a chloride-bicarbonate exchange which is inhibited by histamine through an $\mathrm{H} 1$ receptor but additional effects on other unmeasured ions cannot be excluded.

It is conceivable that the changes in potential difference and short-circuit current were due not to effects of histamine on epithelium but rather to effects on submucosal tissue such as the muscularis mucosae. The specific $\mathrm{H} 1$ blockade demonstrated here could then theoretically represent a demonstration of $\mathrm{H} 1$ receptors on non-epithelial tissues. However, this seems somewhat unlikely, particularly as steady ionic flux changes, reached 15 to 30 minutes after histamine, were shown to be specifically blocked as well.

The observation by Fromm and Halpern ${ }^{17}$ that $\mathrm{H} 1$ receptor blockade alone significantly reduced residual ion flux and bicarbonate secretion suggests the possibility that endogenous histamine may be acting on the mucosa under the basal conditions of their study. However, a comparison of their and our results reveals some discrepancies. Firstly, we could not demonstrate a flux change in response to $\mathrm{H} 1$ receptor blockade alone. This may be due to our having used diphenhydramine, a blocker reputed to have minimal local anaesthetic activity compared with the pyrilamine ${ }^{20}$ primarily used by Fromm and Halpern. It is conceivable that the response to the latter agent was related to its local anaesthetic activity ${ }^{21}$ rather than its $\mathrm{H} 1$ receptor blocking activity. They report a similar response with diphenhydramine but only in a concentration 10 times higher than that used in our study. Secondly, 
their response to $\mathrm{H} 1$ receptor blockade is not in keeping with that expected simply from antagonism to the actions of histamine demonstrated here. Our results would suggest that blockade of any endogenous histamine activity which may have been present should have enhanced bicarbonate secretion (and $\mathrm{Cl}$ absorption) rather than the reverse. While the electrical and flux changes induced by histamine have been shown to be prevented by the $\mathrm{H} 1$ blocker used in our experiments, this and other blockers may also have an action independant of $\mathrm{Hl}$ blocking activity, particularly in high concentrations.

Our observations that aminoguanidine, a histaminase inhibitor, enhances the effect of histamine suggests that histaminases are present in intestinal mucosal preparations and indeed they have been localised in intestinal villous cells ${ }^{22}$. This observation supports the possibility that histamine may have a physiological role in this site. The lack of effect of aminoguanidine alone suggests that it is unlikely that endogenous production of histamine is occurring to an appreciable extent in this in vitro preparation in the basal state.

Preliminary studies of electrical responses to histamine in rabbit jejunal and colonic mucosa and in human colonic mucosa suggest that these regions of the intestine respond in a similar manner (unpublished observations).

It is of interest to contrast the effects of histamine on the stomach with those on the intestine. In the former its activity seems to be mediated through $\mathrm{H} 2$ receptors $^{23}$, while in the intestine it is clear that $\mathrm{H} 1$ receptor mediated activity is responsible for its effect on transport. These data do not, of course, demonstrate a physiological role for histamine in intestinal transport but they do provide a possible mechanism by which absorption may be impaired in circumstances where histamine is liberated locally in the intestine. Such may be the case, for example, in intestinal allergies and systemic mastocytosis.

We are grateful to the Medical Research Council and the North West Regional Health Authority for financial support during this project.

\section{References}

${ }^{1}$ Douglas WW, Feldberg W, Paton WDM, Schachter M. Distribution of histamine and substance $P$ in the wall of the dog's digestive tract. J Physiol 1951; 115:163-76.

${ }^{2}$ Lorenz W, Matejka E, Schmal A et al. A phylogenetic study on the occurrence and distribution of histamine in the gastro-intestinal tract and other tissues of man and various animals. Comp Gen Pharmacol 1973; 4: 229-50.

${ }^{3}$ Douglas WW. Autacoids. In: Goodman LS, Gilman A, eds. The pharmacological basis of therapeutics. New York: MacMillan, 1975: 596-9.

${ }^{4}$ Avery Jones F, Gummer JWP, Leonard Jones JE. In: Clinical gastroenterology. Oxford: Blackwell, 1968; 735. ${ }^{5}$ Corbett CL, Isaacs PET, Riley AK, Turnberg LA. Human intestinal ion transport in vitro. Gut 1977; 18: 136-40.

${ }^{6}$ Field M, Fromm D, McColl I. Ion transport in rabbit ileal mucosa. 1. Sodium and chloride fluxes and short circuit current. Am J Physiol 1971 ; 220:1388-96.

${ }^{7}$ Durbin RP, Heinz E. Electromotive chloride transport and gastric acid secretion in the frog. J Gen Physiol 1958; $41: 1035-47$.

${ }^{8}$ Schild HO. pA, a new scale for the measurement of drug antagonism. Br J Pharmacol 1974; 2:189-206.

${ }^{9}$ Arunlakshana O, Schild HO. Some quantitative uses of drug antagonists. Br J Pharmacol 1959; 14:48-58.

${ }^{10}$ Schild HO. Receptor classification with special reference to B-adrenergic receptors. In: Rang HP, ed. Drug receptors. London: MacMillan, 1973; 29-35.

${ }^{11}$ Reuse JJ. Comparisons of various histamine antagonists. Br J Pharmacol 1958; 3:174-80.

${ }^{12}$ Waton NG. Studies on mammalian histidine decarboxylase. Br J Pharmacol 1956; 11:119-27.

${ }^{13}$ Hill SJ, Young JM, Marrian DH. Specific binding of 3H-mepyramine to histamine $\mathrm{H} 1$ receptors in intestinal smooth muscle. Nature 1977; 270:361-2.

${ }^{14}$ Ash ASF, Schild HO. Receptors mediating some actions of histamine. Br J Pharmacol 1966; $27: 427-39$.

${ }^{15}$ Bareicha I, Rocha-E-Silva M. Occurrence of $\mathrm{H} 2$ receptors for histamine in the guinea pig intestine. Biochem Pharmacol 1975; 24:1215-9.

${ }^{16}$ Lee JS, Silverberg JW. Effect of histamine on intestinal fluid secretion in the dog. Am J Physiol 1976; 231 :793-8.

${ }^{17}$ Fromm D, Halpern N. Effects of histamine receptor antagonists on ion transport by isolated ileum of the rabbit. Gastroenterology 1979; 77:1034-8.

${ }^{18} \mathrm{M}$ arshall PB. Some chemical and physical properties associated with histamine antagonism. Br J Pharmacol $1955 ; 10: 270-8$.

${ }^{19}$ Wilbrandt W. Zur frage des Wirkungsmechanismus der Antihistamin substanzen. Helv Physiol Pharmacol Acta 1950; 8:399-408.

${ }^{20}$ Douglas WW. Autacoids. In: Goodman LS, Gilman A, eds. The pharmacological basis of therapeutics. New York: MacMillan, 1975: 603-13.

${ }^{21}$ Murdoch Ritchie J, Cohen PJ. Local anaesthetics. In: Goodman LS, Gilman A, eds. The pharmacological basis of therapeutics. New York: MacMillan, 1975: 380-2.

${ }^{22}$ Shakir KMM, Margolis S, Baylin SB. Localization of histaminase (diamine oxidase) in rat small intestinal mucosa-site of release by heparin. Biochem Pharmacol 1977; 26:2343-7.

${ }^{23}$ Black JW, Duncan WAM, Durrant CJ, Ganellin CR, Parsons EM. Definition and antagonism of histamine H2 receptors. Nature (Lond) 1972; 236:385-90. 